\title{
Specificity of English-Language Teaching for Senior Learners within the Lifelong Learning Concept
}

\author{
Tatiana V. Savina* \\ Novosibirsk State University \\ of Economics and Management \\ 56 Kamenskaya Str., Novosibirsk, 630099, Russia
}

Received 29.08.2015, received in revised form 12.09.2015, accepted 22.10.2015

The concept of lifelong learning is believed to involve participants of all ages. In Russia, elderly people (senior adults) are mostly interested in less educationally focused activity, but rather personal development within informal learning. A language course is an opportunity for senior adults to stay active and participate in community life. Contrary to stereotypes, senior adults can learn foreign languages successfully, though it requires special teaching and learning techniques when a teacher acts as a facilitator. The article focuses on psychological and age-related specifics in teaching English senior learners when some basic principles of andragogy can be applied: self-actualization, selfevaluation and self-direction of a learner. The grammar and vocabulary content should fully meet the language needs of a senior learner. Adjustments in the learning environment made by a teacher can greatly facilitate the process of learning.

Keywords: lifelong learning, senior adults teaching, senior learner, personal development, andragogy, education in Russia, English teaching, teaching techniques, facilitator.

The article is written with the financial support of the European Commission within the Tempus IV programme (Project "Lifelong Language Learning University Centre Network for New Career Opportunities and Personal Development (UNICO)", № 544283-TEMPUS-1-2013-1-ES-TEMPUSJPHES).

DOI: $10.17516 / 1997-1370-2015-8-11-2606-2613$.

Research area: pedagogy.

\section{Introduction}

In recent years, lifelong learning concept is being adopted in Russia as a term for postcompulsory education that is going on outside of the Russian Federation Higher Education system in forms of informal and non-formal learning. The concept of lifelong learning is widely being discussed in the Russian mass media and professional communities as a prospective national educational strategy, though it is facing a lot of challenges.

Over time, the discourses of LLL changed, starting from the idea of public good to the learning culture as lifestyle (Evans, 2008). Nowadays, the most common perception of the concept is: the more we learn, the more we earn

(c) Siberian Federal University. All rights reserved

* Corresponding author E-mail address: tsavina2005@mail.ru 
(James, Guile \& Unwin, 2013) which responds to the knowledge-based economy needs. The relationships between professional competence development and lifelong learning underlie the majority of social, educational and political strategies in Europe.

The development of the lifelong learning concept in Russia occurs under conditions of the country's accession to the Bologna process in education and even can be regarded as a prerequisite for it. The dominant view that lifelong learning is the "ongoing, voluntary, and self-motivated pursuit of knowledge for either personal or professional reasons"( Department of Education and Science, 2000) beyond the confines of formal higher education is accepted by educational institutions in Russia, which offer a range of additional educational programs for further professional development. The programs are mostly designed for adults with interrupted professional careers or young professionals and are aimed at improving their employability and employment prospects. Such an approach mainly focuses on the question of how to integrate subjectbased and work-based knowledge, educating and training.

However, the lifelong learning concept is not confined only to the expansion of employment opportunities since in that parameter a number of potential learners remain mostly excluded from learning. A broad interpretation of the concept suggests also personal development which takes place under the motto "learn at all ages" and "open up a debate about the nature, scale and location of the learning processes that support the knowledge-based economy" (James, Guile \& Unwin, 2013), thereby extremely expanding a number of participants in lifelong learning and their learning opportunities. The nature of the learning can vary from formal to informal or nonformal, from credit or non-credit in scale, and any place can be regarded as learning space.

\section{Lifelong learning and foreign languages}

The implementation of the lifelong learning concept in Russia can be undertaken provided that the learning process involves any kind of participants at any place. Nowadays, educational institutions mostly provide educational services for adults. Usually it is formal learning aimed at obtaining new qualifications, widening work experience or retraining. Thus, many participants are left out, including learners with finished occupational and learning careers (retired or semi-retired people) who are interested in acquiring new skills rather than new qualifications.

The idea of non-credit informal learning is not new to Russia. There have always been some courses in crafts (knitting, crocheting, scrapbooking), art (drama) or music (choir) provided by local communities for senior adults. However, at the same time, the schemes are mostly regional in nature; provide creative and leisure activities rather than educational opportunities; do not involve large number of participants; and are regarded as part of social work. Russia's lack of educational institutions such as University of the Third Age prevents the greater involvement of older people in the process of learning new skills.

Language courses set a good example of a combination of educational services and new learning opportunities available for senior learners. The courses are to be offered by local universities as non-credit informal learning to help senior adults be participants in lifelong learning with improvements in both their adaptation to a new social status (for those recently retired) and personal satisfaction.

Language courses are in big demand all over Russia because a foreign language competence can significantly improve a person's employability and career opportunities. Senior 
learners who are out of work are completing language courses because of the practical value of learning an additional language, because such a skill may facilitate travel and socializing, or for their own reward. It shows a remarkable change in the learning environment because decades ago senior adults preferred practical activities and pastimes to academic subjects.

\section{Specifics of English teaching}

\section{for senior adult participants in practice}

The English Language course for senior learners was introduced at the Novosibirsk State University of Economics and Management from January to May, 2015, by English teachers of the Foreign Languages Department. There were 30 participants ages 55-62 who participated in a 72-hour English course. The survey conducted before the course showed:

- 80 percent of the participants were retired; 20 percent worked part-time jobs, which did not involve their professional skills;

- the level of English proficiency: a complete starter (all the learners had some experience of learning English at secondary and high school more than 30 years ago).

- 50 percent of the participants had a degree (an accountant, a teacher, an engineer, a computer programmer, an auditor, a manager, etc).

- 50 percent of the participants had qualifications or vocational training in various fields (a cook, a secretary, an officer, a sales assistant, etc).

- two participants spoke a foreign language other than English (French and German);

- of the participants, there were 26 women and four men.

The participants described their language needs were for:

- traveling abroad
- visiting relatives (mostly, children) abroad

- surfing the Internet, and

- personal reward.

The language skills the participants identified as most important were speaking and listening.

The results obtained while teaching outline the main features of the language course for senior learners which is to be held in the framework of informal non-credit education (Afanasieva \& Savina 2015). There are four cornerstones which help the course succeed:

1. Diagnostic study of a learner's profile

2. Appropriate teaching techniques

3. Appropriate course content

4. Assessment

1. Diagnostic study of a learner's profile.

Any language course starts with a learner's placement test to identify a level of English proficiency and set study goals. In our case study, it seems that the results of the diagnostic test (placement test) are often unreliable because older people tend to underestimate their knowledge and are biased towards doing placement tests, a priori considering themselves as a "complete starter." Therefore, at first it is necessary to identify personal language needs of a potential learner rather than a language level. Usually, language needs of senior learners do not go beyond everyday life communication and traveling.

The second factor, which is considered to be essential, is a learner's previous experience of learning English at secondary school. For the majority of the participants, the experience was quite negative, which could develop under the influence of different reasons:

- the lack of motivation of the generation of school students of the 1960s to study foreign languages when there were no opportunities to practice English in communication or workplace (Monk, 1986); 
- the lack of authentic study resources (for example, textbooks or recordings);

- inappropriate teaching techniques when perceptive activities prevailed over productive ones (reading versus listening and speaking)

- a foreign language as a school subject was often regarded as a tool of propaganda (Mayofis, 2014).

Thorough diagnostic study helps not only to identify language needs of participants and set the goals but also to choose the most appropriate teaching methods, which meet the psychological and age characteristics of senior learners.

2. Appropriate teaching techniques. First, senior adults are not readily open to innovative teaching methods like enacting the stories or word games (Anburaj, Christopher \& Ni Ming, 2014). On the other hand, traditional lexical and grammatical approach does not seem productive because, in this case, it is quite difficult to keep learners interested in the subject. There is also a pre-existing knowledge of English grammar, which needs correcting for some learners.

Second, some aspects of language learning become progressively more difficult with age, especially memorizing. Senior adult learners need to review material before and after every class.

Third, most senior learners in Russia do not know how to use laptops, tablets or PCs, which greatly limits the use of technology in the classroom. At the same time, senior adults are eager to do some tasks on PCs, even if they are not experienced users.

Finally, different people study at varying paces. It is absolutely essential to ensure that learners can keep up with each other.

Taking into account the factors mentioned above, we can say that some principles of andragogy (Knowles, ${ }^{1984)}$ can be applied to senior learners teaching:
- self-actualization

- self-evaluation

- self-direction

Self-actualization of a senior learner can be done through communication. The more learners speak to each other and a teacher, the more effective the process of learning becomes, especially when the speaking activity revolves around their lives. Sometimes it is not even necessary to teach learners how to read if they know how to speak. Communication should be the only purpose of the speaking activity: while speaking to learners, a teacher should not correct mistakes or introduce new vocabulary/ grammar because senior adults can easily get confused when you shift to a new topic. Besides, communication helps senior adult learners get rid of the feeling of fear or uncertainty about their ability to speak English - a fear which is inherent to most of them. When a senior learner speaks about things that are familiar to him or her (a family, trips, pets, hobbies, weather, leisure activities), he or she gets more self-confident and has an opportunity to show achievement. Senior adults easily acquire the vocabulary that helps them speak about their children, jobs and other sources of personal pride.

Listening activities can provide selfevaluation of a learner. Listening tasks should be regarded as a key point in teaching senior adults. They consider listening comprehension as one of the toughest activities, possibly because a previous experience of trying to understand conversational speech at high speed with slurred pronunciation and in a stressful situation (e.g. at a hotel or an airport) for many of them was unsuccessful. Thus, while doing listening tasks, a learner can be provided "with opportunities to evaluate their own competence that may facilitate the process of making their skills visible to them" (Kersh, Evans, Kontiainen \& Bailey, 2011). A learner is encouraged to realize 
that he or she can understand what is being said and react somehow to what was heard. But at the same time, a teacher must ensure that a listening task is not too complicated and does not confuse a learner or, even worse, develop a fear of oral communication. It is highly recommended to use very short recordings (two to three phrases), which last 10-15 seconds, on a subject familiar to learners. Senior adults are remarkably good at perceiving videos and movies, especially if it is a movie they've seen in Russian (but the duration of a segment should not be longer than one to two minutes).

The appropriate teaching technique helps a learner with self-direction, or autonomy. It is up to a learner to choose the best way for him or her to learn. Senior adults tend to rely on their own experiences of learning, using some mnemonics or approaches they have already get used to. A teacher should not insist on doing a task that a learner does not find useful to do. On the other hand, there is always a risk to lose control over the learning process. In other words, a teacher and a learner should negotiate all the time: what to learn, how to learn and how much to learn. A teacher's main task is to facilitate the process of learning as much as possible which requires a teacher to be an effective listener and communicator rather than an academic lecturer or university professor.

3. Appropriate course content. A teaching technique, if it is chosen correctly, greatly facilitates the acquisition of a language. The vocabulary content depends on the language needs of participants and can change while the grammatical content may remain the same for all language courses for senior learners. It seems that just the basic knowledge of grammar is enough to communicate successfully but only if it is learned consciously, without cramming. Adult learning is believed to be problem-centered rather than content-oriented (Knowels, ${ }^{1984)}$ so it is recommended to teach grammar patterns which are of practical value for a person when communicating.

The grammatical content of the program for senior adult beginners can be described as follows:

1. Verb tenses: present simple, past simple, future simple, and sometimes present perfect. It does not seem productive if senior adult learners are overloaded with such grammar patterns like the difference between the use of present simple and present continuous, or such as will and going to. They can succeed in conversation having even limited knowledge of English. Moreover, it is necessary to give a direct translation rather than to explain the main idea of a tense.

2. Modal verbs: can, have to, should as far as a speaker is to describe his abilities or obligations while socializing.

3. Structures: positive, negative and interrogative (words order).

4. There is / are (positive, negative and interrogative).

5. The greatest attention should be given to the use of the verbs to be and to have in a wide variety of structures.

A short-term memory is a stumbling block in teaching senior adults. The method of cyclical revision of the study content is most likely to be productive. The content of each subsequent class includes an active revision of the pattern studied. For example, while learning different meanings of the verb to be, a learner first learns how to introduce himself: I am Irina, I am Russian, and then to describe the location: I am at home, I am from Russia; appearance: I am tall and slim; and state and emotions: I am sick, I am upset. They started every class with introducing themselves and were asked to say as much new information as possible about their families, friends, hobbies, etc. At the same time, when exchanging personal information in English, senior adults seemed to 
be exited about getting to know about each other. They ask questions about families or interests. A teacher's role is to facilitate the communication and help with vocabulary. This technique is a kind of mnemonic character and contributes to the long-term memorization of vocabulary.

Vocabulary content which depends on the language needs of each individual study group, however, in general focuses on every-day life activities - family, traveling, holiday (vacation), shopping, interests - as older people usually memorize best what they are interested in, relying on their own life experiences.

4. Assessment. Since teaching senior learners is to be conducted within the informal learning setting, there is no official assessment system other than personal satisfaction, and a teacher acts as a facilitator to help a learner with personal development which may not be assessed. Positive regard and respect are to improve a learner's awareness while any negative teacher's feedback may discourage a learner and easily ruin his or her self-confidence: senior adults are rather sensitive to any kind of praise or objection. However, a teacher should develop his own system of credits basing on "can do" statements which correlate with a learner's language needs.

As senior adults rarely intend to obtain a certificate in English or any other formal certification, final evaluation of their knowledge is not necessary. A teacher can get a feedback proposing some communication activities or a presentation.

\section{Conclusion}

Thus, senior adults can actively participate in lifelong learning obtaining new language skills not for professional but personal development. Teaching English for senior learners has its own specifics, both psychological and age-related. The end justifies the means since a teacher uses all kinds of means to help a senior learner to succeed. Moreover, the beneficial effects of lifelong learning helps senior adults enjoy opportunities to socialize when traveling, staying active and participating in community life.

\section{References}

Ambrose, S., Bridges, M., Lovett, M., DiPietro, M. \& Norman, M. How learning Works. 7 Research-Based Principles for Smart Teaching. Jossey-Bass, 2010. 302 p.

Armitage, A., Evershed, J. Teaching and Training In Lifelong Learning. Berkshire, Open University Press. 2012. 467 p.

Afanasieva, L. \& Savina, T. (2015). Osobennosti prepodavaniia angliiskogo iazyka pozhilym liudiam $\mathrm{v}$ ramkakh kontseptsii lifelong learning (obuchenie $\mathrm{v}$ techenie vsei zhizni) [Teaching English For Elderly People In Lifelong Learning]. Vestnik Rossiiskogo Universiteta Druzhby Narodov, (4).

Anburaj, G., Christopher, G. \& Ni Ming. (2014). Innovative Methods of Teaching English Language. IOSR Journal Of Humanities And Social Science, 19(8), Ver. IV, 62-65.

Barrall, I. \& Rogers, J. Lifestyle. English for work, socializing and travel. Elementary Coursebook with Self-study CD-ROM. Pearson-Longman, 2011. 160 p.

Bourn, D. (2001). Global Perspectives in Lifelong Learning. Research in Post-Compulsory Education Journal, 6(3), 325-338. doi: 10.1080/13596740100200112.

Davis, B. Tools for Teaching. Jossey-Bass. 2009. 562 p.

Evans, K. (2008) Entries on lifelong learning, transitions and skills. The International Encyclopaedia of Education, Routledge. 
Hansman, C. Adult Learning in Communities of Practice. Communities of Practice. Vol. 1. Chapter 15. Creating Learning Environment for Educators. Information Age Publishing, 2008, pp. 293-310.

James, L., Guile, D. \& Unwin L. (2013)Learning and innovation in the knowledge-based economy: beyond clusters and qualifications. Journal of Education and Work, 26(3).

Kersh, N., Evans, K., Kontiainen, S. \& Bailey H. Use of conceptual models in self-evaluation of personal competences in learning and in planning for change. International Journal of Training and Development, 15(4), 290-305. 2011. doi: 10.1111/j.1468-2419.2011.00387.x

Knowles, M. S. Andragogy in action: Applying modern principles of adult education. San Francisco, Jossey-Bass, 1984. 56 p.

Knowles, M. The Modern Practice of Adult Education: From Pedagogy to Andragogy. Cambridge. 1988. $62 \mathrm{p}$.

Lifelonglearningrussia's Blog. Blog IABS/Russia on issues of lifelong learning in Russia. Available at: https://lifelonglearningrussia.wordpress.com. (accessed 27.10.2015).

Materials of the National Observatory on Vocational Education and Training, available at: http:// www.cvets.ru/deyat4.html (accessed 17.10.2015).

Mayofis, M. (2014). Inostrannyi iazyk dlia "vnutrennego upotrebleniia": obraz Drugogo v uchebnikakh angliiskogo iazyka 1945-1956 gg. [Foreign Language For Internal Consumption: Image Of “The Other" In English Textbooks In 1945-1956]. Problemy sovremennogo obrazovaniia [Issues of the Modern Education], 6, 176-200, available at: http://www.pmedu.ru/index.php/ru/zhurnaly-2014-g/ vypusk-6, in Russian. (accessed 25.09.2015).

Mehisto, P. \& Scott, D. (1986). Language Teaching and Learning. Cambridge, 2012. 154 p.

Monk, B. Foreign Language Teaching in the Soviet Union: continuing the trend. Journal of Russian Studies, 1(150), 28-37.

Yildirim, R. Adopting Communities of Practice as a Framework for Teacher Development. Communities of Practice. Vol. 1. Chapter 12. Creating Learning Environment for Educators. Edited by Chris Kimble and Paul Hildreth. Information Age Publishing, 2008, pp. 233-254. 


\title{
Особенности преподавания английского языка
}

\author{
возрастным ученикам в рамках концепции \\ «Обучение в течение всей жизни»
}

T.В. Савина

Новосибирский государственный университет

экономики и управления

Россия, 630099, Новосибирск, ул. Каменская, 56

Концепция «Обучение в течение всей жизни» предполагает участие в получении новых знаниий и обучении новым навыкам людей всех возрастов. В России пожилые люди по окончании профессиональной карьеры редко стремятся к обновлению профессиональных знаниий, однако готовы получать новые навыки в целях личностного развития. Изучение иностранного языка - одна из самых популярных возможностей личностного развития пожилых людей. Статья рассматривает психологические и возрастные особенности обучения иностранному языку людей старшего возраста, методика которого основывается на некоторых принципах андрагогики: самореализация, самооценка и стремление к самостоятельности взрослого участника учебного процесса. Грамматическое и лексическое содержание учебного курса полностью определяется потребностями ученика в коммуникации на иностранном языке, а задача преподавателя - всемерно облегчить его изучение и адаптировать обучение под языковые нужды возрастного ученика.

Ключевые слова: обучение в течение всей жизни, обучение людей старшего возраста, возрастные ученики, андрагогика, образование в России, личностное развитие, преподавание английского языка, методика преподавания.

Статья написана при финансовой поддержке гранта программы ТЕМПУС IV Европейского Союза (проект «Создание сети университетских языковых иентров для профессионального и личностного развития человека в рамках парадигмы «образование в течение всей жизни», № 544283-TEMPUS-1-2013-1-ES-TEMPUS-JPHES).

Научная спещиальность: 13.00.00 - педагогические науки. 